\title{
QUEEN'S
UNIVERSITY
BELFAST
}

\section{National identity in a foreign context: Irish women accounting for their children's national identity in England}

NiMaolalaidh, M., \& Stevenson, C. (2014). National identity in a foreign context: Irish women accounting for their children's national identity in England. Discourse \& Society, 25(2), 245-262.

https://doi.org/10.1177/0957926513516049

\section{Published in:}

Discourse \& Society

\section{Document Version:}

Peer reviewed version

Queen's University Belfast - Research Portal:

Link to publication record in Queen's University Belfast Research Portal

\section{General rights}

Copyright for the publications made accessible via the Queen's University Belfast Research Portal is retained by the author(s) and / or other copyright owners and it is a condition of accessing these publications that users recognise and abide by the legal requirements associated with these rights.

Take down policy

The Research Portal is Queen's institutional repository that provides access to Queen's research output. Every effort has been made to ensure that content in the Research Portal does not infringe any person's rights, or applicable UK laws. If you discover content in the Research Portal that you believe breaches copyright or violates any law, please contact openaccess@qub.ac.uk. 


\section{Discourse \& Society \\ http://das.sagepub.com/}

National identity in a foreign context: Irish women accounting for their children's national identity in England

Méabh Ní Maolalaidh and Clifford Stevenson

Discourse Society published online 31 January 2014

DOI: $10.1177 / 0957926513516049$

The online version of this article can be found at:

http://das.sagepub.com/content/early/2014/01/28/0957926513516049

Published by:

@SAGE

http://www.sagepublications.com

Additional services and information for Discourse \& Society can be found at:

Email Alerts: http://das.sagepub.com/cgi/alerts

Subscriptions: http://das.sagepub.com/subscriptions

Reprints: http://www.sagepub.com/journalsReprints.nav

Permissions: http://www.sagepub.com/journalsPermissions.nav

>> OnlineFirst Version of Record - Jan 31, 2014

What is This? 


\title{
National identity in a foreign context: Irish women accounting for their children's national identity in England
}

Discourse \& Society

$1-18$

(C) The Author(s) 2014

Reprints and permissions: sagepub.co.uk/journalsPermissions.nav DOI: |0.1।77/09579265।35|6049 das.sagepub.com

@SAGE

\author{
Méabh Ní Maolalaidh \\ University of Limerick, Ireland
}

\section{Clifford Stevenson}

Queen's University Belfast, UK

\begin{abstract}
Social psychologists have attempted to capture the ideological quality of the nation through a consideration of its taken-for-granted quality, whereby it forms an unnoticed 'banal' background to everyday life and is passively absorbed by its members in contrast to its 'hot', politically created and contested nature. Accordingly, national identity is assumed to be both passively absorbed from the national backdrop and actively acquired through national inculcation. This raises the question of how national identity is expressed, transmitted and acquired in a foreign context, where the banal national backdrop is unavailable to scaffold identity and the national resources for identity transmission may be unavailable. The present article addresses this gap by examining the situation of Irish women raising children in England. Critical discursive analyses of the 16 interviews revealed that all women treated their children's national identity and the issue of transmitting identity as dilemmatic: passive transmission risks children passively absorbing English, but active transmission contravenes the assumed naturalness of national identity and can furthermore conflict with children's own personal choice. These results point to the complex interaction between the management of national identity and the broader personal and national context within which this occurs.
\end{abstract}

\section{Keywords}

Children, discourse, foreign context, identity, ideological dilemma, Irish, national identity, transmission, women

\section{Corresponding author:}

Méabh Ní Maolalaidh, Department of Psychology, Faculty of Education \& Health Sciences, University of Limerick, Limerick, Ireland.

Email: meabhnim@eircom.net 


\section{Introduction}

\section{Discursive approach to national identity}

Social psychological attempts to understand the unique hold of the nation on the individual have taken two complementary approaches. On the one hand, the work of Billig (1995) on the 'banal' nature of nationalism argues that the nation has its ideological hold on the populace by virtue of its largely unnoticed presence in our lives. The nation state forms the pervasive backdrop to our daily existence, marking the symbols and institutions of our societies as well as providing and shaping the milieu of media, currency and language though which we act out our lives. In contrast, other research has focused on the active construction and dissemination of national identity by influential national leaders as the source of the power of the nation. As the work of Reicher and Hopkins (2001) demonstrates, national leaders draw on the many historic, cultural, political, economic and psychological aspects of the nation to create a vision of nation in their public rhetoric which both maximises the leader's influence and mobilises the population. The hold of the nation on the populace is therefore determined by the degree to which this construction is consensualised and accepted by the populace.

This relationship between these 'banal' and 'hot' forms of nationalism has in turn been found to inform the display and management of people's national identity in everyday talk. Research has found that nationals can present their national identity as either hot or banal, according to the national context in which it occurs. The work of Condor $(1996,2000)$ on English national identity indicates that in conversational interactions people tend to downplay the strength of their English national identity and present it as banal, assumed and taken for granted in order to distance themselves from the racist and xenophobic associations with English nationalism. They typically do this through an appeal to the naturalness and inevitability of their identity, given where they were born and are currently living. In contrast, in Scotland, Scots typically treat hot proactive claims to national identification as normatively appropriate (Kiely et al., 2001). In the context of a contested national identity where the very constitutional framework is a matter of debate and national independence a possibility, Scottishness is understood as a matter of proactive choice and self-determination.

Likewise, interviews with adolescents (Stevenson and Muldoon, 2010) and students (Joyce et al., 2013) living in the Republic of Ireland indicate that these participants also describe and display their national identity as natural, inevitable and taken for granted. This is typically done through an appeal to the ubiquity of Irishness in the cultural, recreational and educational practices of Irish society. Irishness is depicted as a natural and inevitable backdrop and as passively absorbed from this cultural milieu rather than actively taught or learned. Active assertions of Irishness are treated by these participants as unusual, pathological or inauthentic displays of Irishness. In contrast, Irish adolescents living in Northern Ireland, in a context where Irishness is contested and opposed, display an understanding of Irishness as requiring proactive assertion and active transmission. These students report seeking out opportunities to display and celebrate their Irishness, giving accounts of being encouraged by their parents, peers and teachers to adopt an Irish identity in their home life as well as in school. Much like the Scots, an 
appeal to an unproblematic banal national backdrop is not possible and consequently national identity is inevitably a 'hot' topic.

In sum, the study of strategic banality indicates that groups understand and display their national identity relative to the national context in which they occur. They suggest that a national backdrop, which is understood to be banal, provides discursive resources with which to present national identity as natural, taken for granted and authentic. In other contexts, where the national backdrop is disputed or absent, this mode of identity display is not available to nationals and hence the learning and display of national identity is more likely to be understood and accepted to be proactive. Consequently, the experience and transmission of national identity are likely to occur differently among those nationals living outside of their nation state within a foreign context.

\section{Transmitting a national identity in a foreign context}

Research on national identity in foreign contexts has typically examined how national identity (as a particular form of ethnic identity) is experienced, shaped by context and transmitted among members and between generations. In effect, the absence of an indigenous national background or culture throws into sharp relief the need to explain how a decontextualised national identity is maintained and transmitted without external cultural support. From a sociological perspective, this is reflected in the different processes affecting first- and second-generation immigrants. For a first generation with a previously developed sense of national identity, 'socialisation' must be an active process whereby they attempt to adopt a place within the host community while maintaining their previous national identity. In contrast, the second generation will be exposed to the different host and ethnic cultural influences from birth and will both passively and actively absorb these elements from different sources. Unlike first-generation immigrants, the second generation does not need to blend or accommodate different pre-existing national identities; instead the process of acquiring their ethnicity is by identifying with and committing to the norms and values of the ethnic and host groups (Hynie et al., 2006).

Such differences in experience have been found to be a source of intergenerational conflict. Immigrant parents can become more authoritarian and try to maintain their cultural origin by setting limitations on their children's behaviour. For example, in Asian Indian families the parent-child conflict is centred on dating, relationships, marriage and career (Dasgupta, 1989; Hynie, 1996; Tang and Dion, 1999). Restrictions on children's recreational, and especially sexual, activities outside the home are often met with resistance (Castillo et al., 2004; Farver et al., 2002), as children often become socialised in the new culture and reject their parents' influence. Indeed, as Ying (1999) points out, in the context of immigrants to the USA, ethnic families have an additional risk of family conflict because the different rate of acculturation between foreign-born parents and their US-raised children results in a 'cultural gap' between generations (Dugsin, 2001; Ying and Chao, 1996).

In terms of intergenerational transmission, Yuval-Davis (1993) argues that women in particular are the main reproducers of the nation biologically, culturally and symbolically. In addition to the conflicting and competing demands typically associated with 
motherhood, immigrant mothers are often understood as being responsible for the transmission of national identity to the next generation (Gray and Ryan, 1998) and more generally as keepers of traditional culture (Mosse, 1985; Thapar-Björkert and Ryan, 2002). However, women who emigrate are less likely to be able to guarantee this; intermarriage jeopardises the biological reproduction of 'authentic' race and emigration discontinues 'authentic' nationalism. Those who fail to successfully transmit national identity can also be perceived as abandoning their responsibilities to the family, and threaten the continuity and survival of the community by reducing the population (Ryan, 2007). In other words, a mother's failure to pass on national identity is a highly accountable matter.

Overall, this research provides prima facie evidence that the lack of a national backdrop congruent to one's national identity problematises both the maintenance and the transmission of this identity, with serious consequences for migrants and their children. Conversely, it points to the pivotal role of banal nationalism in sustaining and transmitting national identity in an unnoticed way in one's home nation. However, such a conclusion is premature as there are of course factors affecting the identities and lives of international migrants in different national contexts. The present study aims to clarify this matter by exploring how immigrant mothers in a foreign context account for the emerging national identities of their foreign-born children.

\section{Case study: Irish mothers in England}

Historically, relations between Ireland and England have been heavily influenced by issues arising from their shared history, the independence of the Irish Free State and the governance of Northern Ireland. Such issues include the partition of Ireland and its constitutional relationship with and obligations to the UK following independence, as well as the period of political violence in Northern Ireland from the 1960s to the 1990s known as 'the Troubles'. In addition, the high level of trade, their proximate geographic location, common language and migration link these two states. The equivalent reciprocal rights and entitlements and a Common Travel Area between the countries make England an attractive option for many Irish emigrants; an estimated 14 million people in Britain claim to have Irish parents or grandparents (2001 consensus). In the last few hundred years, migration to England has been more or less constant (Davis, 2000; O'Connor, 1972), particularly in the 1950s and the 1980s, with another recent peak since 2008, all coinciding with economic recessions in Ireland.

Despite these links and the shared population, the historic colonial past has created opposition between Irish and English national identity (Tovey and Share, 2003). This poses a challenge for Irish diaspora in terms of maintaining and transmitting an Irish national identity to avoid acquiring an English national identity. There is some evidence of tension between first- and second-generation Irish, particularly those born into English society. Walter (2004) found that second-generation Irish identity is constructed as 'inauthentic' in England and Ireland, making it difficult for individuals of Irish parentage to make an Irish background claim. This results in individuals self-identifying as bicultural 'half Irish/half English'. Walter claims that this is not a biological division, but indicates a difference between their 'public' and 'private' lives: growing up and being educated in 
one culture and being immersed in the family culture at home. Similarly, Scully (2009) demonstrated that 'authenticity' is an important aspect of how Irish identity is constructed by first- and second-generation Irish migrants in England. He argued that Irish diasporic identity is constructed as authentic through either transnational knowledge or diaspora claims. The former authenticity is constantly challenged by the 'new arrival' Irish migrants in comparison with Irishness in Ireland, while diaspora authenticity is challenged by both 'new arrivals' and second-generation Irish as either progressive and modern or old and culturally static.

This population is therefore an ideal site to investigate issues of ethnic identity in a foreign context. As noted above, immigrant mothers are particularly invested with the role of identity maintenance and transmission within the family, and doing this within the national context of the other poses additional challenges. On this basis, the key research question is: How do Irish mothers account for the national identity of their children in an English context? Theorists in psychology treat national identity as assumed or as an aspect of political rhetoric, but do not consider it in terms of the national context. The present research demonstrates that national identity that is not in the national context is complicated and is a concern for people.

\section{Method}

The present study recruited 16 Irish mothers who had emigrated to England in the 1970s and 1980s. The interviews were conducted between 1992 and 1994, a time when the place of Irish immigrants had improved dramatically from previous decades, but also when the Northern Ireland conflict still caused tensions between Irish immigrants and their hosts in England. Respondents were between 24 and 45 years of age and had children of diverse ages. Some women had infants and preschool children ranging from two months to four years, some had school-aged children and others had older teenagers (see Appendix 1 for details).

Women were interviewed in their homes using an open-ended semi-structured schedule which covered various aspects of their experience in England, including their perceptions of the identities of their own children. All interviews were audio-recorded and transcribed verbatim using the transcription system of Gail Jefferson for conversational analysis (Jefferson, 2004), for the purposes of fine-grained interpretation (see Appendix 2). To ensure the anonymity of participants, pseudonyms were used.

Analysis involved a coding system which identified instances where women problematised their children's national identity, and expressed or oriented to what was problematic as well as how they attempted to manage and resolve such problems. Critical Discourse Analysis (CDA) (Wetherell and Edley, 1999) was then employed to analyse the discursive repertoires used by the women to negotiate this topic, as well as the various subject positions adopted by the women to negotiate the representation of their children's national identity. CDA has been demonstrated to effectively link the analysis of located discursive action to the broader ideological backdrop of everyday life. In particular, it affords an identification of the 'dominant' ways of conceptualising and articulating social phenomena, the dilemmas encountered in the tensions and contradictions within these discourses, and the stances or 'subject positions' adopted to negotiate these complexities. 


\section{Data and analysis}

\section{The dominant repertoire}

This section identifies the 'dominant repertoire' (normatively appropriate way of talking) used by first-generation Irish women to describe their children's national identities. In this repertoire, children's national identity is presented as unproblematic, banal and taken for granted. Three recurring patterns emerged in women's talk that afforded a representation of their children's Irishness as 'assumed'. These included physical appearance, Irish ancestry and Irish passports, which were used to reflect the automatic nature of these children's Irishness.

In the following extract, Ailbhe draws on facts about her children's Irish appearance to justify their Irish national identity. Their stereotypical Irish physical features indicate that their Irishness is 'out-there' (Potter, 1996). In other words, this aspect of Irishness is assumed to be factual rather than simply a personal opinion.

\section{Extract 1}

1. I: How are they perceived in school?

2. Ailbhe: (3.0) Em

3. I: Do they get a hard time?

4. Ailbhe: (2.0) They can do (1.0) yes

5. I: How does that make you feel?

6. Ailbhe: (3.0) If they look Irish I mean people know-they know Irish

7. kids if they look Irish my kids look Irish (1.0) they have

8. lots of freckles and the red hair and people and kids

9. cotton on to their Irishness because of their looks

Ailbhe draws on stereotypical Irish characteristics to describe her children's Irishness: they have 'lots of freckles and the red hair'. She argues that her children are treated by others as Irish because of these physical characteristics. Ailbhe claims that this is a generic assumption; there is a general consensus that children with such features are Irish. This corroborative factualising of children's Irishness exonerates Ailbhe from the accusation of having a personal stake in her children being Irish. Instead, their Irishness is common knowledge, 'out-there', rather than it being Ailbhe's personal opinion.

Another aspect of children's identity that could be used to essentialise their Irishness is their ancestry. Kiely et al. (2005) argued that ancestry was an aspect of Scottishness which was relatively unimportant within the boundaries of the nation, but in the following extract ancestry is made relevant to children's national identity in England.

\section{Extract 2}

1. I: How would you describe your child's identity or nationality

$2 . \quad$ should I say?

3. Fiona: Em (2.0) English father and= Irish mother except I hasten

4. to add (1.5) that the father has Irish roots which are probably 
5. $\quad$ more (1.0) em= (3.0) bona fide than mine (1.0) mine are very

6. Protestant

7. I: (2.0) And what's her nationality (2.0) do you think?

8. Fiona: (2.0) I think while she is here she'll be (2.0) half (1.5) English

Fiona draws on the parents' ancestry in an attempt to justify her daughter's Irishness. Although the father is English, Fiona works up his Irishness by attending to his Irish Catholic ancestry. Fiona, on the other hand, is first-generation Irish and her own Irishness is uncontested. She plays her Irishness down, claiming that her husband's Irishness is more authentic than her own 'Protestant' roots. This playing down of her Irish ancestry can be done without risking a loss of her Irishness, while playing up the father's Irishness is a strategic move implying that his Irishness contributes to their daughter being Irish. This argument implies that the combination of the parents' Irishness and Irish ancestry justifies describing her daughter as Irish.

The interviewer shifts the focus from the parents' national identity back to the initial request to describe her child's nationality. Fiona responds by shifting from parental ancestry to blaming her daughter's Englishness on living in England; while they live in England, she will possess a bicultural national identity. However, this implies that if they move to Ireland she will just be Irish. It is worth noting that Fiona's husband's Englishness is not drawn on to describe her daughter's Englishness. A possible reason is that this would essentialise her Englishness, whereas making her Englishness contingent on living in England can be resolved by moving to Ireland.

Alternatively, Irish women could invoke 'official' understandings of Irishness and use passports to bolster children's potential claims to Irish national identity. Kiely et al. (2005) claimed that in Britain there is a distinction between 'state identity' and 'national identity'. The former refers to civic identity, being legally British, while national identity alludes to ancestry, such as being English, Scottish or Welsh. In the following extract, we see that the civic and ethnic can be combined or separated depending on what is being achieved in the interaction.

\section{Extract 3}

1. I: Em how would you describe their nationality?

2. (2.0) The kids?

3. Eithna: I don't >@know@<@@@@(2.0) It's really funny

4. because- well my husband is American and the older

5. $\quad$ one is like American (1.0) I'm Irish and they're English

6. $\quad>/$ I have to accept that $<(1.0)$ even though they are on

7. my husband's American passport and on my

8.> >@passport@<

Eithna argues that both parents have managed to maintain their national identity in England, but their oldest daughter has not. However, unlike her oldest daughter, who was born in America, her other children were born in England. Rather than using place of birth as an argument to justify her children's Irish nationality, Eithna draws on the parents' passports. However, this does not resolve the problem of her children's Englishness 
for Eithna, as she claims it is her duty to accept her children's Englishness - 'I have to accept that' (line 6).

Civic national identity is treated as banal identity, something that is factual and taken for granted. However, Eithna indicates that although she makes this assumption, her children's national identity is not determined by their passport, but by their country of residence.

\section{Subordinate repertoire}

Interviewees also adopted an alternative repertoire of proactive transmission of national identity: in effect, teaching their children how to be Irish. However, this was demonstrably 'subordinate' in that it was treated as problematic and accountable by participants who invariably oriented to it as requiring more qualification, explanation and justification than the self-evident and stand-alone accounts presented in the previous section. In the following two extracts, the women report the proactive transmission of Irishness to their children by ensuring that their children are involved in stereotypical Irish cultural activities, frequenting Ireland and presenting Irishness positively.

\section{Extract 4}

1. I: Would you encourage her to be Irish?

2. Róisín: Yeah (1.0) I would make her aware of where she comes

3. from and make her feel that it's alright- (1.0) it's ok to feel

4. Irish (2.0) that's how I would encourage her to be Irish

5. that it's a good thing to be Irish

\section{Extract 5}

1. I: Do you encourage them to be Irish?

2. Áine: You should talk to my husband

3. I: How does he encourage them?

4. Áine: Well he (5.0) sort of he (1.0) follows the rugby, and Irish

5. football And sort of he'd be pushing the Irish music and

6. football and the rugby and anything Irish on the telly and

7. going home he's very keen to take them home every

8. year

In these extracts, the women report proactive transmission of Irishness. However, in each extract they also treat this proactivity as somehow problematic, either by indicating that it is undesirable or by justifying it as a response to a deficiency or challenge to their children's Irishness. Róisín's account is notably less fluent, more complex and orienting to a wider range of concerns than those in the previous section. Her concern is ensuring that her children are knowledgeable about their Irish ancestry and promoting Irishness as positive in the hope that her children will choose to be Irish. However, it is notable that in this instance there is an implied outgroup that is being evoked here by using anti-Irish discourse: 'it's a good thing to be Irish' (extract 4, line 5). This interview was conducted 
in the early 1990s when there was political unrest in Northern Ireland and bombing by the IRA in London. Anti-Irish discourse was dominant during this time (cf. Hickman and Walter, 1997). Thus, a likely concern for Irish women was that negative perceptions of Irishness would inhibit their children in choosing to be Irish. Rather than proactively transmitting Irishness, Róisín is compensating for the absence of and opposition to Irishness.

Áine manages the challenge of accounting for proactive identity transmission in a different way, by attributing responsibility for this to her husband. She claims he actively encourages stereotypical activities, such as Irish sports, music and awareness of Irishness. Scully (2012) noted that these proactive displays of Irishness were perceived as 'old fashioned' and inauthentic by Irish 'new arrivals' and second-generation Irish in England, whereas Áine treats her husband's proactive transmission as him having a stake in their children being Irish, and described his behaviour as accountable - 'he'd be pushing' (extract 5, line 5). Áine's account of this excessive transmission by her husband indirectly positions her as being more reasonable through the relative passivity of her transmission style. In this way, proactive transmission is treated as strategic by Áine rather than as a display of inauthenticity.

These extracts illustrate the existence of a second repertoire of identity transmission which focuses on proactive transmission. However, notably, in these cases transmission was not presented as natural and inevitable, and across these different formulations women displayed a much higher level of accountability for the proactive transmission of Irishness. They minimised their proactive role, justified it in relation to deficiencies in their children's identities or placed responsibility for the proactive transmission elsewhere. In other words, this is a secondary, subordinate repertoire to the first, and one which is normatively problematic for women.

\section{Ideological dilemma and subject positions}

The key dilemma faced by participants was that while passive transmission of Irishness is treated as preferable, a failure to inculcate Irishness risks allowing one's children to become English. Passive transmission ensures the recreation of an Irish national identity that resembles the way Irish national identity is understood to occur in Ireland, passively and banally absorbed from the national context. However, this passive transmission runs the risk of children automatically becoming English through absorbing the national culture of the host state. The alternative is being a 'proactive' transmitter, but this is seen as less preferable and less authentic by many of the participants and also as potentially conflicting with the wishes and choices of their children. In addition to the more general challenges of motherhood (Russo, 1976), the competing injunctions of passing on identity and fostering children's own preferences come to the fore.

Women manage this dilemma by shifting between a number of subject positions which are afforded by their relationship with their children and spouse. Women with younger children tend to defer the issue; they treat their children as requiring proactive transmission at present but it is problematised in the future, and they hope that being passive will produce Irishness. On the other hand, women with older children do not have this resource, but can articulate a developmental narrative as "going through a phase" to discount any deficit in their children's Irishness. 
Mothers with young children. In the following extract, Róisín makes her child's age relevant to proactively and passively transmitting Irishness. She claims to be proactive in the present because her children are young, but she predicts being passive in the future by accepting her child's counter opinion.

\section{Extract 6}

$\begin{array}{lll}\text { 1. I: } & \text { How would you describe your children's identity? your } \\ \text { 2. } & \text { child's identity should I say? (2.0) her nationality? (1.0) } \\ \text { 3. } & \text { Róisín: } & \text { I think of her as Irish (2.0) Em= tha- I think that will } \\ \text { 4. } & \text { change accor=ding to what view she has as well (1.0) I } \\ 5 . & \text { think I will have to accept that she has to see= how she } \\ 6 . & & \text { wants to be herself (H) but given her age I think- (1.0) I- I } \\ 7 . & \text { think of her very much as an Irish child (2.0) } \\ 8 . & \text { I: } & \text { Do you think there is a certain age that- that-(1.0) } \\ 9 . & \text { Róisín: } & \text { Well I think that what she says will matter and she may- } \\ 10 . & \text { (1.5) I accept fully that she may feel English because she } \\ 11 . & \text { lives here (1.0) and that mightn't be easy for me but if she } \\ 12 . & \text { feels that then I'll have to respect that I think }\end{array}$

Róisín uses the subordinate repertoire of active transmission by claiming that her daughter is Irish, but she also adopts a more passive stance in predicting that this position will change in the future. Her position as a new mother affords this construction, as her young child cannot at present choose her own identity, and so any potential conflict is necessarily deferred to the future. This shift in the determination of identity is presented by Róisín as a duty, such that she is obliged to move from an active to a passive role. However, the implication is that the issue is not problematic at present because of her daughter's age. While she is not 'speaking back', Róisín must proactively transmit Irishness.

The interviewer questions Róisín about the age when this change will occur. Róisín indicates that she would be passive by accepting her daughter's feeling of Englishness, but she explicitly emphasises that this would be problematic for her (lines 10-11). Róisín resolves the problem by blaming her daughter's Englishness on living in England. She manages the conflict between her children potentially feeling English and having to passively respect their Englishness, by evoking the conditional logic argument, 'if ... then' (Levinson, 1983). If her daughter feels English, then it is Róisín's duty to respect her English national identity.

In the next extract, Deirdre likewise defers the problem of proactive transmission to the future, when her child has grown up. She uses the dominant discourse of natural, automatic identity transmission to problematise active transmission.

\section{Extract 7}

1. Deirdre: You know I'd like to be involved with more Irish- Irish

2. things (1.0) then I hate (clear throat) you know the Irish

3. centres type of things (0.5) I'd like Máire to you know do

4. Irish dancing but I couldn't bear the notion of the 


\begin{tabular}{|c|c|c|}
\hline 5. & & costumes and the ringlets and the (1.0) Feises and the \\
\hline 6. & & 'instinctive Irish mother' bit like having to- but I hope we could \\
\hline 7. & & find something that I can live with and that she likes so it's \\
\hline 8. & & hard to know how to tap into that in (1.0) here in the four \\
\hline 9. & & walls in the family em (1.0) so- \\
\hline 10. & Deirdre: & You know a nice thing with a friend of mine up the road \\
\hline 11. & & (1.0) you know and em Tom's parents are Irish and he \\
\hline 12. & & grew up in London and ( 0.5$)$ his parents were Irish and \\
\hline 13. & & they are not at all religious (1.0) and they have a very- \\
\hline 14. & & their children are living here and they- they are born and \\
\hline 15. & & bred Londoners they are very $(1.5)>/$ Irish $/<$ and- and- \\
\hline 16. & & em (2.0) you know in their opinion like they see \\
\hline 17. & & themselves as- as Irish and then (1.0) you know their \\
\hline 18. & & house and the things in it (1.0) em (1.0) so those people \\
\hline 19. & & like that have given me great hope I think that we can \\
\hline 20. & & preserve it \\
\hline 21. & I: & Yeah (1.0) I think it can be a problematic thing- \\
\hline 22. & Deirdre: & Well not at the moment \\
\hline 23. & $\mathrm{I}:$ & Yeah until it actually comes up \\
\hline 24. & Deirdre: & Yeah she is still very young \\
\hline
\end{tabular}

Deirdre manages the conflict between passive and active modes of identity transmission by setting up a series of contrasts between the need to use the artificial and stereotypical Irish cultural resources available in England and her own opinion of these resources. She highlights a conflict between wanting her daughter to do Irish dancing, while disliking the costumes and dancing competitions. Although Deirdre dislikes the Irishness that is available, she indicates being accountable for the transmission of some Irishness, and hopes to somehow find suitable Irish activities for her daughter.

Deirdre's account also highlights the key role played by the home in transmitting Irishness. She claims her Irish friends manage to passively transmit Irishness to their children in the home, without doing so proactively. Rather than parents being agents in the transmission of Irishness, 'things' in the house are depicted as banally flagging Irishness in the home.

These young mothers both claim to be proactive transmitters in the present, while their children are young, but predict being passive in the future. There is concern that being passive will result in their children being English, which they claim to resolve by transmitting Irishness. However, there is also a problem with being proactive, because it entails transmitting an undesirable Irishness. These mothers resolve this conflict by claiming to unproblematically speak on behalf of their children while they are young, and deferring the problem to the future. This proactive transmission of Irishness resembles the management of second-generation Irish - 'overstretching' Irishness runs the risk of looking inauthentically Irish (Walter, 2004).

Mothers with teenage children. In contrast, mothers with older children are constrained to a different subject position. As their children are in a position to express an affinity for a national identity, the problem for these mothers is allowing the children to choose their 
identity while also ensuring they choose to be Irish. Unlike young mothers, these mothers have the additional concern of their children 'speaking back', and the conflicts arising from children not choosing to be Irish. This problem is resolved by mothers drawing on a developmental narrative.

In extract 8 , Ailbhe displays her proactive transmission of Irishness as problematic because it is counter to the popular opinion outside the home with which her children concur (i.e. the preference is to be English). This is resolved by treating the children's choice as a phase that will change in the future.

\section{Extract 8}

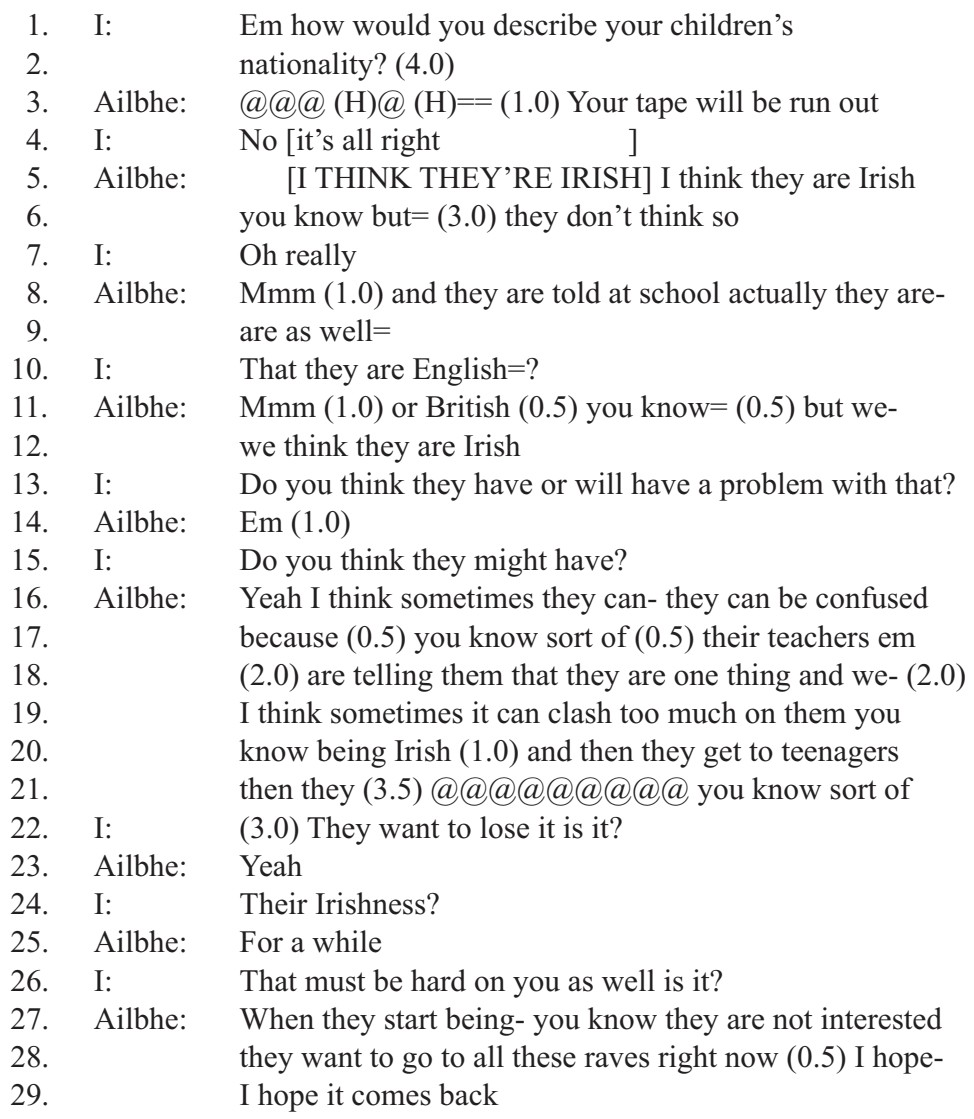

Ailbhe negotiates the challenges of proactively transmitting Irishness to her teenage children. This is presented as problematic because Ailbhe's opinion is counter to the view of her children and the school. Outside the home, her children do not consider themselves Irish and they are told at school that they are British.

The interviewer enquires whether this difference in opinions between parents and school is problematic for her children. Ailbhe explains that the contrast between the 
transmission of Britishness at school and parents transmitting Irishness at home creates confusion for her children. However, she indicates that the transmission of Irishness is problematic. Where Britishness is banally absorbed at school and socially with peers, Irishness is being proactively transmitted in the home, which is problematic because 'it can clash too much on them' (line 19).

In order to reconcile these tensions, Ailbhe evokes a developmental narrative to justify the shift in her children's preference not to be Irish. Her children prefer going to raves rather than doing Irish activities. Ailbhe treats this as a phase - 'for a while' (line 27). In other words, it is something they will outgrow, and Ailbhe hopes they will return to being Irish in the future.

In the following extract, Peig also evokes a developmental narrative to resolve the issue of her child's preference for being English. Unlike Ailbhe, the problem is presented retrospectively; it was a phase that occurred in the past.

\section{Extract 9}

1. Peig: (H) But she did say to me once I mean em (1.0) when she was

2. about five or six em we were passing the Catholic school

3. here right and= she said to me (2.0) ' $>/$ I don't think I'm

4. Irish' $<(2.0)$ we were having some wicked rows about that

5. because I kept saying to her 'but Niamh you're $\mathrm{Ir}=\mathrm{ish}=\mathrm{of}$

6. course you're Irish' (mimic) and she'd say 'No I'm English'

7. (mimic) and she said 'Well if I was Irish I'd be going to that

8. school, that's where all the Irish go. You sent me to a

9. different school so how could I be Irish?' (mimic)

10. I:@@@@@@@@@

11. Peig: Of course there is that sense that, if you are not a Catholic then

12. you are not a part of the Irish community you know that (1.0)

13. she's changed her attitude now when she was seven

14. and eight and nine she went through this real sort of- it was

15. kind of a rebellion against us em (1.0) 'No I'm not Irish I

16. insist I want an English passport' because she'd been

17. on a holiday with a friend=(1.0) so she needed a

18. passport without us (1.0) and we said 'Ok' I said 'do you

19. want an Irish or an English passport'? she said 'of

20. course I want an English passport' (mimic)

21._@@@@@@@@@@@@

22. I:@@@

23. Peig: But she's changed now [you know]

24. I: [Did ] that upset you when she

$25 . \quad$ was like that?

26. Peig: $>/ \mathrm{We}=\mathrm{l}=\mathrm{l}=<$ it $\mathrm{did}$ a bit yes it did but $\mathrm{I}$ mean in a way $\mathrm{I}$

27. could see it as a bit- (there she is) I could see it as a bit of a game=

28. that we were playing

Peig recalls two occasions when her daughter disclaimed being Irish. The first was in relation to the school she attends. Peig claimed that Niamh blames her lack of Irishness 
on Peig's decision to send her to a non-Catholic school. This fact is used by Niamh to justify her interpretation of Peig's decision to send her to this school. She argues that this decision means Peig perceives her as English rather than Irish. Peig undermines Niamh's accusation by treating it as a childish interpretation. She evokes an 'active voice' (Wooffitt, 1992) to illustrate the exchange that occurs between them. Peig mimics her daughter's voice to demonstrate how this displays being childish. However, Peig follows with a reflexive comment about her daughter's opinion, that there is some truth in the fact that children who attend Catholic schools are usually associated with being Irish.

A second occasion that Peig's daughter disclaimed being Irish was when she required an independent passport. Peig presented herself as a reasonable mother by offering her daughter the option of having either an Irish or English passport. Peig claimed that Niamh responded by preferring to have an English passport: 'of course I want an English passport' (lines 19-20). This response indicates that there was already an established assumption that Niamh would prefer to have an English passport, and Peig's offering of a choice was in fact provocative and disingenuous. In characterising her daughter in this way, as an unreasonable teenager, Peig treats her daughter's preference to be English as a retrospective phase which she has outgrown, thus indicating that the problem has now been resolved.

Unlike mothers with young children, mothers with teenage children have the additional problem of their children's counter opinions. Parents' proactive transmission is reported to be treated as problematic by children, in the same way that participating in Irish activities and events by established first-generation Irish diaspora was problematised by 'new arrivals' from Ireland (Scully, 2012). However, in the present study the women indicate a need to be proactive to ensure their children choose to be Irish. Children also problematised parents being passive, blaming them for being English by not being a proactive transmitter. Thus, mothers with teenage children are in a no-win situation both passive and proactive transmissions are problematised by their children.

The key finding emerging from the data is that mothers talk differently about their children's identity depending on their age. Women with young children adopt a proactive transmission approach on behalf of their children. Those with older children encounter conflict and are forced to be passive.

\section{Discussion}

The present research aimed to examine how immigrants account for identity transmission in a foreign context, outside of the banal backdrop of their home nation. We examined how Irish women account for their children's identity in the context of England. Our results indicate complex identity-related concerns and management strategies which centre on the competing understandings of what it is to be Irish abroad, and the duty of transmitting Irishness to the next generation in the absence of a banal national backdrop.

The implications of these results for the study of national identity in social psychology are fourfold. First, it is evident, as with the Irish adolescents in Northern Ireland (Stevenson and Muldoon, 2010), that these participants understand, display and negotiate their national identities within the broader national context of their lives. In Stevenson 
and Muldoon's (2010) research, the 'hot' nature of Irish identity could well have been due to the idiosyncratic nature of contested national identities in the Northern Ireland conflict, but in the present research it is more clearly attributable to the lack of a 'banal' national backdrop. Indeed, as well as demonstrating subtle identity management strategies in their accounts, our participants explicitly tell us about the challenges of bringing up children outside of Ireland. In other words, this goes some way to throwing into relief the important role of the banal national backdrop in shaping the maintenance and transmission of national identity, and more generally of the relations between national context and national identities in everyday life.

Second, our results speak to the literature on intergenerational transmission of identity. Previous research has suggested that tensions between parents and children result from the qualitatively different processes of acculturation of pre-existing identities and enculturation of new identities in the second generation (Ying, 1999; Ying and Chao, 1996). Our results show why this may be the case. These mothers treat their children's identities as reflecting on their own duty and ability to successfully transmit the correct form of Irishness to their children. We show that the emerging national identity of these children is a highly accountable matter for immigrant mothers. We argue that the role of managing the national identity of children is one potential source of the ideological reproduction of nationalism in the diasporic community and contributes greatly to the development of national identity in children.

Third, our results suggest that while previous research has highlighted the problems facing mothers (and parents more generally) in the transmission of national identity to children of different ages, we found that parenting afforded a number of subject positions from which parents could reflexively negotiate these issues. While theorists have looked at the unique role of mothers in transmitting identities, our participants themselves strategically invoke their partners as strategic resources in sharing responsibility for the national identity of their children. Parents of young children could use their youngsters' insensibility to choose an identity for them or, if faced with disagreement from older offspring, could attribute apparently unsuccessful identity transmission to a developmental (typically 'teenage') phase. In other words, we show that the family dynamics and developmental processes inherent in the intergenerational transmission of identity among immigrants do not simply 'happen' to parents and their children, but both shape their concerns and form discursive resources for parents to negotiate the challenges that transmission poses.

Following on from this point, our results lastly suggest a model whereby the dominant ideological forces of nationalism can be seen to provide both the injunctions and strictures which structure and inform the concerns of everyday life, but also provide the conceptual resources from which identity is fashioned and managed. Rather than passive dupes of the hegemonic discourses of nationalism or alternatively isolated decontextualised confabulators of identity, our participants are active and strategic managers of the challenges posed to them by hegemonic discourses in the context of their daily lives. While our research is necessarily limited by the sample, the specific context of AngloIrish relations and the time period of the data collection, we would suggest that this research goes one step further towards an appreciation of how nationality is imbricated in the lived practices of everyday life and the fibre of family dynamics, and of how these 
intimate places form the space where national identity is negotiated and transformed as well as reproduced.

\section{Funding}

This research received no specific grant from any funding agency in the public, commercial or not-for-profit sectors.

\section{References}

Billig M (1995) Banal Nationalism. London: SAGE.

Castillo L, Conoley CW and Bossart DF (2004) Acculturation, white marginalization, and family support as predictors of perceived distress in Mexican American female college students. Journal of Counseling Psychology 51: 151-157.

Condor S (1996) Unimagined community: Some social psychological issues concerning English national identity. In: Breakwell G and Lyons E (eds) Changing European Identities: Social Psychological Analyses of Social Change. London: Butterworth-Heinemann, pp. 41-67.

Condor S (2000) Pride and prejudice: Identity management in English people's talk about 'This Country'. Discourse \& Society 11: 175-205.

Dasgupta SD (1989) Gender roles and cultural continuity in the Asian Indian immigrant community in the US. Sex Roles 38: 953-974.

Davis G (2000) The Irish in Britain, 1815-1939. In: Bielenberg A (ed.) The Irish Diaspora. Harlow: Pearson Education, pp. 65-88.

Dugsin R (2001) Conflict and healing in family experience of second generation emigrants from India living in North America. Family Process 40: 233-241.

Farver JAM, Narang SK and Bhadha BR (2002) East meets West: Ethnic identity, acculturation, and conflict in Asian Indian families. Journal of Family Psychology 16: 338-350.

Gray B and Ryan L (1998) The politics of Irish identity and the interconnections between feminism, nationhood and colonialism. In: Pierson RR and Chaudhuri N (eds) Nation, Empire, Colony: Historicizing Gender and Race. Bloomington, IN: University of Indiana Press, pp. 120-138.

Hickman M and Walter B (1997) Discrimination and the Irish Community in Britain. London: Campaign for Racial Equality.

Hynie M (1996) From conflict to compromise: Immigrant families and the process of acculturation. In: Taylor DM (ed.) Diversity with Justice and Harmony: A Social Psychological Analysis. Prepared for Strategic Policy, Planning and Research and Metropolis Project, Citizenship and Immigration Canada, pp. 97-123. Available at: http://canada.metropolis.net/research-policy/ litreviews/tylr_rev/tylr_rev-08.html\#CONFLICT (accessed 20 September 2009)

Hynie M, Lalonde $\bar{R} N$ and Lee N (2006) Parent-child value transmission among Chinese immigrants to North America: The case of traditional mate preferences. Cultural Diversity \& Ethnic Minority Psychology 12: 230-244.

Jefferson G (2004) Glossary of transcript symbols with an introduction. In: Lerner GH (ed.) Conversation Analysis: Studies from the First Generation. Philadelphia, PA: John Benjamins, pp. 13-31.

Joyce C, Stevenson C and Muldoon O (2013) Claiming and displaying national identity: Irish Travellers' and students' strategic use of 'banal' and 'hot' national identity in talk. British Journal of Social Psychology 52(3): 450-468.

Kiely R, Bechhofer F, Stewart R, et al. (2001) The markers and rules of Scottish national identity. Sociological Review 49: 33-55. 
Kiely R, McCrone D and Bechhofer F (2005) Whither Britishness? English and Scottish people in Scotland. Nations and Nationalism 11(1): 62-82.

Levinson SC (1983) Pragmatics. Cambridge: Cambridge University Press.

Mosse GL (1985) Nationalism and Sexuality: Respectability and Abnormal Sexuality in Modern Europe. New York: Howard Fertig.

O'Connor K (1972) The Irish in Britain. London: Sidgwick \& Jackson.

Potter J (1996) Representing Reality. London: SAGE.

Reicher S and Hopkins N (2001) Self and Nation: Categorization, Contestation and Mobilization. London: SAGE.

Russo N (1976) The motherhood mandate. Journal of Social Issues 32: 143-153.

Ryan L (2007) Who you think you are? Irish nurses encountering ethnicity and constructing identity in Britain. Ethnic and Racial Studies 30: 416-438.

Scully M (2009) 'Plastic and proud'? Discourses of authenticity among the second-generation Irish in England. Psychology and Society 2: 124-135.

Scully M (2012) The tyranny of transnational discourse: 'Authenticity' and Irish diasporic identity in Ireland and England. Nations and Nationalism 18: 191-209.

Stevenson C and Muldoon OT (2010) Socio-political context and accounts of national identity in adolescence. British Journal of Social Psychology 49: 583-599.

Tang TN and Dion KL (1999) Gender and acculturation in relation to traditionalism: Perception of self and parents among Chinese students. Sex Roles 41: 17-29.

Thapar-Björkert S and Ryan L (2002) Mother India/Mother Ireland: Comparative gendered dialogues of colonialism and nationalism in the early 20th century. Women's Studies International Forum 25: 301-313.

Tovey H and Share P (2003) A Sociology of Ireland, 2nd edn. Dublin: Gill \& Macmillan.

Walter B (2004) Irish women in the diaspora: Exclusions and inclusions. Women's Studies International Forum 27: 369-384.

Wetherell M and Edley N (1999) Negotiating hegemonic masculinity: Imaginary positions and psycho-discursive practices. Feminism \& Psychology 9: 335-356.

Wooffitt R (1992) Telling Tales of the Unexpected: The Organisation of Factual Discourse. Hemel Hempstead: Havester Wheatsheaf.

Ying YW (1999) Strengthening intergenerational/intercultural ties in migrant families: A new intervention for parents. Journal of Community Psychology 27: 89-96.

Ying YW and Chao CC (1996) Intergenerational relationships in lu Mien American families. Amerasia Journal 22(3): 47-64.

Yuval-Davis N (1993) Gender and nation. Ethnic and Racial Studies 16: 421-432.

\section{Author biographies}

Méabh Ní Maolalaidh completed her PhD in the Department of Psychology, Faculty of Education and Health Sciences at the University of Limerick. She is currently doing postdoctoral research on the experience of visiting Irish diaspora and how they are perceived in Ireland. Her research interests include qualitative methods, ethnicity and nationalism, minorities and diaspora.

Clifford Stevenson, $\mathrm{PhD}$, is a Senior Lecturer at Queen's University Belfast. His research interests include applying qualitative methods to the investigation of the display and enactment of collective identities in interaction. His current research spans the study of citizenship and participation in everyday life; displays of national identity and banal nationalism; community identity, stigmatisation and intergroup contact. 


\section{Appendix I}

\section{Participants' details}

\begin{tabular}{lllll}
\hline Number & Category & $\begin{array}{l}\text { Pseudonym of } \\
\text { women }\end{array}$ & Age of women & Age of children \\
\hline 1 & Young mother & Róisín & 41 & 4 \\
2 & Young mother & Deirdre & 33 & 1,4 \\
3 & Young mother & Fiona & 37 & 2 \\
4 & Established mother & Peig & 45 & 12 \\
5 & Established mother & Ailbhe & 47 & $3,7,9,13,15$ \\
6 & Established mother & Áine & 48 & $9,10,15,16$ \\
7 & Established mother & Eithna & 36 & $5,6,14$ \\
\hline
\end{tabular}

\section{Appendix 2}

\section{Transcription notations}

This research used the transcription symbols developed by Gail Jefferson to analyse women's turnby-turn talk. Commas and full stops are used to make reading transcripts easier.

A dash indicates the sharp cut-off of the prior word or sound.

(0.4) The number in round brackets measures the pauses in seconds (in this case, four tenths of a second).

$\backslash / \quad$ Backward slash $(\backslash)$ indicates a fall in intonation, forward slash (/) indicates a rise in intonation.

$><\quad$ The 'more than' and 'less than' signs indicate that the talk between these is notably different; it can be quieter, louder, said with laughter, e.g. $(>/ \mathrm{We}=\mathrm{l}=\mathrm{l}<)$.

$=\quad$ The 'equals' sign indicates an extended word or sound.

@ The 'at' sign indicates laughter; the more '@'s, the longer the laughter.

"I THINK" Cap text indicates a strong emphasis on the these words.

[ ] Squared brackets between adjacent lines of concurrent speech indicates the onset and end of overlapping talk, e.g.

I: [It's all right ]

Ailbhe: [I THINK THEY'RE IRISH] 